\title{
PAYDAY LOANS AND CREDIT CARDS: NEW LIQUIDITY AND CREDIT SCORING PUZZLES?
}

\author{
Sumit Agarwal \\ Paige M. Skiba \\ Jeremy Tobacman \\ Working Paper 14659 \\ http://www.nber.org/papers/w14659 \\ NATIONAL BUREAU OF ECONOMIC RESEARCH \\ 1050 Massachusetts Avenue \\ Cambridge, MA 02138 \\ January 2009
}

We would like to thank David Abrams, Stefano DellaVigna, Jonathan Levin, Devin Pope, Nicholas Souleles, and Maisy Wong for very valuable comments and advice. The views expressed herein are those of the author(s) and do not necessarily reflect the views of the National Bureau of Economic Research.

NBER working papers are circulated for discussion and comment purposes. They have not been peerreviewed or been subject to the review by the NBER Board of Directors that accompanies official NBER publications.

(C) 2009 by Sumit Agarwal, Paige M. Skiba, and Jeremy Tobacman. All rights reserved. Short sections of text, not to exceed two paragraphs, may be quoted without explicit permission provided that full credit, including $\odot$ notice, is given to the source. 
Payday Loans and Credit Cards: New Liquidity and Credit Scoring Puzzles?

Sumit Agarwal, Paige M. Skiba, and Jeremy Tobacman

NBER Working Paper No. 14659

January 2009

JEL No. D03,D14,D82

\begin{abstract}
$\underline{\text { ABSTRACT }}$
Using a unique dataset matched at the individual level from two administrative sources, we examine household choices between liabilities and assess the informational content of prime and subprime credit scores in the consumer credit market. First, more specifically, we assess consumers' effectiveness at prioritizing use of their lowest-cost credit option. We find that most borrowers from one payday lender who also have a credit card from a major credit card issuer have substantial credit card liquidity on the days they take out their payday loans. This is costly because payday loans have annualized interest rates of at least several hundred percent, though perhaps partly explained by the fact that borrowers have experienced substantial declines in credit card liquidity in the year leading up to the payday loan. Second, we show that FICO scores and Teletrack scores have independent information and are specialized for the types of lending where they are used. Teletrack scores have eight times the predictive power for payday loan default as FICO scores. We also show that prime lenders should value information about their borrowers' subprime activity. Taking out a payday loan predicts nearly a doubling in the probability of serious credit card delinquency over the next year.
\end{abstract}

Sumit Agarwal

Financial Economist

Federal Reserve Bank of Chicago

230 South LaSalle Street

Chicago, IL 60604-1413

sumit.agarwal@chi.frb.org

Paige M. Skiba

Vanderbilt University Law School

131 21st Avenue South

Nashville, TN 37203-1181

paige.skiba@vanderbilt.edu

\section{Jeremy Tobacman}

Business and Public Policy Department

1459 Steinberg Hall-Dietrich Hall

3620 Locust Walk

The Wharton School

University of Pennsylvania

Philadelphia, PA 19104-6372

and NBER

tobacman@wharton.upenn.edu 


\title{
Payday Loans and Credit Cards: New Liquidity and Credit Scoring Puzzles?*
}

\author{
Sumit Agarwal Paige Marta Skiba Jeremy Tobacman
}

January 13, 2009

Among the many important questions highlighted by recent events in the financial sector, one concerns the features and determinants of the liability side of households' balance sheets, and a second concerns the measurement of household creditworthiness. Had households taken on and accumulated debt with more wisdom and caution, and had lenders obtained and relied on more meaningful measures of creditworthiness, foreclosure rates might now be more moderate.

Using a unique dataset matched at the individual level from two administrative sources, we examine household choices between liabilities and assess the informational content of prime and subprime credit scores in the consumer credit market. (In abbreviated fashion, we aspire to follow the similar inquiries of Adams, Einav and Levin (forthcoming) in the auto market context.) First, more specifically, we assess consumers' effectiveness at prioritizing use of their lowest-cost credit option, while (Agarwal, Chomsisengphet, Liu and Souleles 2007b) examine the choice between two different credit card contracts with different costs, here we find that most borrowers from one payday lender who also have a credit card from a major credit card issuer have substantial credit card liquidity on the days they take out their payday loans. ${ }^{1}$ This is costly because payday loans have annualized

\footnotetext{
*Agarwal: Federal Reserve Bank of Chicago, 230 South LaSalle Street, Chicago, Illinois 60604-1413, ushakri@yahoo.com. Skiba: Vanderbilt University Law School, 131 21st Avenue South, Nashville, TN 37203-1181, paige.skiba@vanderbilt.edu. Tobacman: University of Pennsylvania and NBER, 3620 Locust Walk, 1459 SHDH, Philadelphia, PA 19104-6372, tobacman@wharton.upenn.edu. We would like to thank David Abrams, Stefano DellaVigna, Jonathan Levin, Devin Pope, Nicholas Souleles, and Maisy Wong for very valuable comments and advice. JEL Codes: D14 (Personal Finance), D91 (Intertemporal Consumer Choice; Life Cycle Models and Saving).

${ }^{1}$ The term "payday loan" is used because these loans provide liquidity between paydays. The typical loan is due on the borrower's next payday, and hence has a duration of between
} 
interest rates of at least several hundred percent, though perhaps partly explained by the fact that borrowers have experienced substantial declines in credit card liquidity in the year leading up to the payday loan. Second, we explore the relationship between prime and subprime credit scoring. In this we follow (Agarwal, Chomsisengphet, Liu and Souleles 2007a), who use a dataset combining all the credit relationships held by a sample of bank customers, to explore the relative value of different sorts of information in predicting consumer default on a given product, including outside credit bureau information and FICO scores, internal information from the bank's behavior scores for the individual product, and "relationship" information from the behavior of the other products held by the customer. Here we use our matched sample of credit cards and payday loans, from which we observe FICO scores and scores from the subprime credit bureau Teletrack. This payday lender only used Teletrack scores to make loan approval decisions for first-time applicants, though conditional on the Teletrack score higher FICO scores predict higher repayment rates by economically and statistically significant amounts. We show that the two scores have independent information and are specialized for the types of lending where they are used: Teletrack scores have eight times the predictive power for payday loan default as FICO scores. We also show that prime lenders should value information about their borrowers' subprime activity. Taking out a payday loan predicts nearly a doubling in the probability of serious credit card delinquency over the next year. The rest of the paper explains how we arrive at these facts and discusses the extent to which they present puzzles for standard models.

\section{Merged Administrative Datasets}

Our analysis takes advantage of an unusual, individual-level match of two administrative data sources. Specifically, we have used individual identifiers to merge loan records from a large payday lender with transaction and credit histories from a financial institution that offers checking accounts, credit cards, mortgages, home-equity lines of credit, and auto financing. For detailed description of the two datasets, we refer readers to sources that have used them separately in the past (Agarwal, Driscol, Gabaix and Laibson 2008, Skiba and Tobacman 2008a, e.g.). Online Appendix Tables A1 and A2 respectively summarize characteristics of the individuals and accounts in what we'll refer to here as the payday lender and credit card issuer

one week and one month (Caskey 1994, Stegman 2007). 
panels. In all that follows, we include the 102,779 people who borrowed on a payday loan from this payday lender (i.e., we exclude unsuccessful payday loan applicants) and had a full set of background variables, and the 143,228 people with credit card accounts at the credit card issuer in the states where the payday lender operates.

Tables A1 and A2 also report information about the matched sample of 3090 people, and this selected group is statistically different from both the full credit card issuer population and the full payday lender population on most measures. ${ }^{2}$ Payday borrowers' average incomes are much lower, though the variation in their incomes is also much lower. Their accounts are older, and their credit lines smaller. Intriguingly, the income data from the credit card issuer for the matched sample are higher by 50 percent than the income data from the payday lender for the matched sample. The number of open credit card accounts with balances is almost identical, as is the amount of outstanding credit card debt. Home equity line and mortgage balances are also similar.

One important measure on which the matched sample differs less than we expected is the FICO score. Among all credit card account holders the average FICO score is 730, with a standard deviation of 69 , compared to 673 for the matched sample. The standard deviation for the matched sample is slightly smaller than for the full credit card population. Conventionally, the subprime population is viewed as having scores below 620 , implying that a large share of payday borrowers likely have continuing access to prime credit. In the data, FICO scores are current as of the previous month.

Below we focus on questions that are of interest within the selected matched sample, and we analyze the causes and aftermath of the selection itself.

\section{Liquidity's Decline}

Using this matched dataset, we first examine how effectively consumers choose between payday loans and credit cards. One summary measure suggests a common pecuniary mistake: two-thirds of the matched sample has

\footnotetext{
${ }^{2}$ Out of the entire Texas population of roughly 20 million, the overall (non-random) payday loan coverage rate is about three-quarters of one percent. The credit card issuer panel includes 23,795 Texas-based accounts. Thus if the payday loan and credit card samples were orthogonal we would expect to obtain only 180 matches, while we actually have 1707 Texas-based matches out of the 3090 matches overall. Presumably much of the difference arises because only adults can borrow on credit cards and payday loans, and because both products attract people who seek credit.
} 
at least $\$ 1000$ of credit card liquidity on the day they take their first payday loans, much more than the typical $\$ 300$ payday loan. For a two-week payday loan with a finance charge of 18 percent, using credit card liquidity first would save these households $\$ 300 *\left(0.18-\left(1.18^{1 / 26}-1\right)\right)=\$ 52$, if the credit card APR is 18 percent. Appendix Table A3 elaborates on how credit card liquidity and APRs vary across the population on the days people take their payday loans. Most notably, liquidity is strongly increasing in credit scores; married credit card account holders had almost twice the liquidity of singles; and credit card liquidity was much higher for the elderly. Across these distributions, most people in the matched sample appear to have credit card liquidity exceeding the size of the typical payday loan.

Since many payday borrowers take loans repeatedly, we also construct a measure called LOSS that cumulates interest losses over the one year beginning with each borrower's first payday loan. Specifically, for the $i$ 'th person in the matched dataset, we compute $L O S S_{i}$ as follows. Suppose individual $i$ takes $n_{i}$ payday loans within a year of her first loan, including her first loan, on dates $\left\{d_{i 1}, d_{i 2}, \ldots, d_{i n_{i}}\right\}$, where $d_{i 1}=0$ and $d_{i n_{i}} \leq 365$ $\forall i$. Denote the size of $i$ 's $k$ 'th payday loan by $b_{i}\left(d_{i k}\right)$; the length or term of that loan in days by $t_{i}\left(d_{i k}\right)$; available credit card liquidity on the date of $i$ 's $k$ 'th loan by $l_{i}\left(d_{i k}\right)$; and $i$ 's prevailing credit card gross APR on the same date by $R_{i}^{c c}\left(d_{i k}\right)$. Finance charges are fixed for payday loans at $r^{p d l}=18$ percent. $^{3}$ Then $L O S S_{i}=\sum{ }_{k=1}^{n_{i}} \max \left[\min \left[b_{i}\left(d_{i k}\right), l_{i}\left(d_{i k}\right)\right], 0\right] *$ $\left[r^{p d l}-\left(R_{i}^{c c}\left(d_{i k}\right)^{t_{i}\left(d_{i k}\right) / 365}-1\right)\right]$.

Figure 1 plots the histogram of $L O S S$, including the share of credit card customers who have $L O S S=0$ because they have no credit card liquidity when they borrow from the payday lender. Typical credit card account holders would have saved almost $\$ 200$ by borrowing up to their credit card limits before turning to payday loans. ${ }^{4}$

A number of other authors including Gross and Souleles (2002), Bertaut and Haliassos (forthcoming), and Agarwal et al. (2007b) have measured similar liquid debt "puzzles" using other data. Consensus is elusive, but the size of the interest losses found elsewhere (with more representative samples) tends to be smaller on average than what we measure. Telyukova and Wright (2008) further explore liquidity needs as an explanation for the credit card

\footnotetext{
${ }^{3}$ To emphasize again, this is a per-loan proportional charge, not an APR.

${ }^{4}$ Appendix Table A4 shows the impact of demographic variables on LOSS. Our results suggest that losses decline with income and credit risk characteristics. Additionally they are higher for married couples. One potential explanation is that married couples are more likely to seek payday loans to hide expenditures from their spouse.
} 
debt puzzle. The current paper's results are notable because (i) the interest losses are shown to be very large, (ii) since the individuals in our matched dataset might borrow on payday loans elsewhere and might have access to other sources of liquidity, we believe we're measuring a lower bound on the actual interest losses, and (iii) over ten million US households borrow on payday loans each year.

Our findings complement existing research on the causes of payday borrowing patterns (Caskey 1994, Skiba and Tobacman 2008b, e.g.) and survey evidence about the alternatives available to payday borrowers. Regarding the latter, a nationally representative sample of one thousand payday loan customers, surveyed by Elliehausen and Lawrence (2001), found 56.5 percent of respondents in possession of bank-issued credit cards. However, of the individuals with cards 61 percent hadn't used them in the past year in order to avoid exceeding the cards' credit limits. A collection of other representative surveys across six states conducted by IoData (2002) and covering 2600 payday borrowers found 55 percent in possession of credit cards. Again, access to liquidity for these respondents might nonetheless have been limited, as only 34 percent "almost always" or "sometimes" paid monthly credit card balances in full. Across these surveys, the anticipation of rejection caused two-thirds of respondents not to apply for credit on at least one occasion in the past five years.

Table 1 presents information about the path that credit card liquidity takes during the year leading up to a customer's first payday loan. Several features of the data are apparent in Table 1. First, credit card liquidity falls by $\$ 545$ over the previous year on average, an amount that is much larger than the average $\$ 300$ size of a first-time payday borrower's loan. Second, most of the deterioration in liquidity happens in the five months before the payday loan is taken. This is interesting because it speaks to the question of why people borrow on payday loans. If liquidity were flat until a large drop one month before the payday loan application, we would suspect that a single large bad shock had unexpectedly arrived. Since we find average liquidity falling steadily, impatience, general financial mismanagement, or persistent shocks seem more likely explanations. Third, deterioration happens across the distribution of credit card liquidity, and the standard deviation falls substantially. However, fourth, combined with the declines in liquidity across the board, there is substantial heterogeneity. The people at the top (with the most liquidity) don't decline very fast; the people at the bottom have little further to descend; and the upper-middle group collapses. These numbers offer some insight into how households' cash flow can evolve, as well as illustrating the process of selection from the full credit card population into 
the matched sample.

\section{Information from Prime and Subprime Credit Scores}

By examining the separate and combined predictive power of the FICO and Teletrack scores for the matched sample, which is publically available to firms, higher-quality information may emerge for lenders. The correlation coefficient between the FICO and Teletrack scores within the matched sample is 0.2555 , implying substantial differences between the two scores, presumably because Teletrack scores emphasize information from subprime lenders (including car title lenders and rent-to-own establishments, in addition to payday lenders). In a prior study, Agarwal et al. (2007a) study the impact of relationships a credit card holder has with her bank (deposits, loans, and investments) on credit card defaults. They find that privately available information about deposit, loan and investment accounts is highly predictive of credit card defaults.

In Appendix Tables A5-A6 we report estimates from a series of regressions. The first series examines what the credit card variables predict about payday loan sizes and payday loan default. The payday loan default (logit) regression illustrates new and valuable information about the relative value of prime and subprime credit scores. The FICO score's coefficient is very large in absolute value, with a t-stat of 15 and a 1sd increase predicting a default probability that is lower by 7.6 percentage points. This makes it somewhat puzzling FICO is not used to evaluate payday loan applications. However, the coefficient we find on the Teletrack score is $(-0.0601 /-0.0270)=2.23$ times the magnitude of the coefficient on the FICO score, and (as reported in Table A1) the standard deviation of Teletrack scores is 4.18 times as large as the standard deviation of the FICO score in the matched sample. Thus the Teletrack score has more than eight times as much power for predicting payday loan default as FICO does, suggesting why payday lenders might prioritize Teletrack scores over FICO scores in making lending decisions.

Table A6 focuses on the question of what the payday loan variables predict about credit card usage and default. Usage is defined here as outstanding debt divided by the limit. The most important result speaks to the value credit card companies might place on knowledge that an account holder had taken out a payday loan. Define "serious" credit card delinquency as an indicator for whether an account becomes 90 days past due (90dpd) at any 
point during the following year. Then a logit of $90 \mathrm{dpd}$ on credit card control variables and an indicator for whether or not a payday loan is taken implies that taking a payday loan predicts a 92 percent higher serious delinquency rate. Overall in the credit card issuer data, the annual serious delinquency rate is 6 percent, so we are finding an increase of about 5.5 percentage points in this rate. Selection issues have been discussed above, but a credit card lender might well be more interested in the joint implication of the treatment (the payday loan) and the selection (that the account holder is looking for very expensive credit).

Because we don't observe borrowing at other payday lenders, our estimate is a lower bound on the true predicted increase in credit card default risk following a borrower's initial payday loan. These findings suggest credit card issuers might find information about account holders' payday borrowing very valuable, insofar as it provides sufficient advance warning to limit or rein in credit. We are left with two possible puzzles: why do payday lenders generally use only Teletrack scores and not also FICO scores when making lending decisions, and why do credit card issuers not aggressively seek information about payday borrowing by their customers?

\section{Conclusion}

This paper identifies and discusses possible liquidity and credit scoring puzzles. Regarding liquidity, we find that most account holders with a major credit card issuer have substantial unused liquidity on their credit cards at the time they borrow on payday loans. Their annual pecuniary losses from payday borrowing, compared to using their credit cards, are large compared to previously identified liquid debt puzzles. Regarding credit scores, payday lenders could obtain useful information about default probabilities by examining the FICO scores of applicants in addition to Teletrack scores, and credit card issuers would benefit from having frequently-updated information about whether their account holders are payday borrowers.

We conjecture that small costs could at least begin to explain these phenomena. Credit bureaus charge lenders small fees for each score query, and those fees might exceed the value of the marginal creditworthiness information obtained. On the consumer side, Zinman (2009) and Borzekowski and Kiser (2008) discuss models of account-specific characteristics that can incorporate the realistic variety of pecuniary, non-pecuniary, and cognitive costs. They point in promising directions for explaining this paper's new facts. 


\section{References}

Adams, William, Liran Einav, and Jonathan Levin, "Liquidity Constraints and Imperfect Information in Subprime Lending," American Economic Review, forthcoming.

Agarwal, Sumit, John Driscol, Xavier Gabaix, and David Laibson, "Learning in the Credit Card Market," 2008. Available at http://ssrn.com/abstract=1091623.

, Souphala Chomsisengphet, Chunlin Liu, and Nicholas Souleles, "Benefits of Relationship Lending: Evidence from the Consumer Credit Market," 2007. Working Paper, University of Pennsylvania.

__ _ _ _ , and _ _ _ Do Consumers Choose the Right Credit Contracts?," 2007. Available at SSRN: http://ssrn.com/abstract=843826.

Bertaut, Carol and Michael Haliassos, "Debt Revolvers for Self Control," Review of Finance, forthcoming. University of Cyprus mimeo.

Borzekowski, Ron and Elizabeth Kiser, "The Choice at Checkout: Quantifying Demand Across Payment Instruments," International Journal of Industrial Organization, July 2008, 26, 889-902.

Caskey, John P., Fringe Banking: Check-Cashing Outlets, Pawnshops, and the Poor, New York: Russell Sage Foundation, 1994.

Elliehausen, Gregory and Edward C. Lawrence, Payday Advance Credit in America: An Analysis of Customer Demand, Credit Research Center, Georgetown University, 2001.

Gross, David and Nicholas Souleles, "Do Liquidity Constraints and Interest Rates Matter for Consumer Behavior? Evidence from Credit Card Data," Quarterly Journal of Economics, February 2002, 117 (1), 149-185.

IoData, "Payday Advance Customer Research: Cumulative State Research Report," September 2002.

Skiba, Paige Marta and Jeremy Tobacman, "Do Payday Loans Cause Bankruptcy?," 2008. University of Pennsylvania mimeo.

and ___ "Payday Loans, Uncertainty, and Discounting: Explaining Patterns of Borrowing, Repayment and Default," 2008. University of Pennsylvania mimeo. 
Stegman, Michael, "Payday Lending," Journal of Economic Perspectives, Winter 2007, 21 (1), 169-190.

Telyukova, Irina and Randall Wright, "A Model of Money and Credit, with Application to the Credit Card Debt Puzzle," Review of Economic Studies, 2008, 75 (2), 629-647.

Zinman, Jonathan, "Debit or Credit?," Journal of Banking and Finance, February 2009, 33 (2), 358-366. http://dx.doi.org/10.1016/j.jbankfin.2008.08.009. 


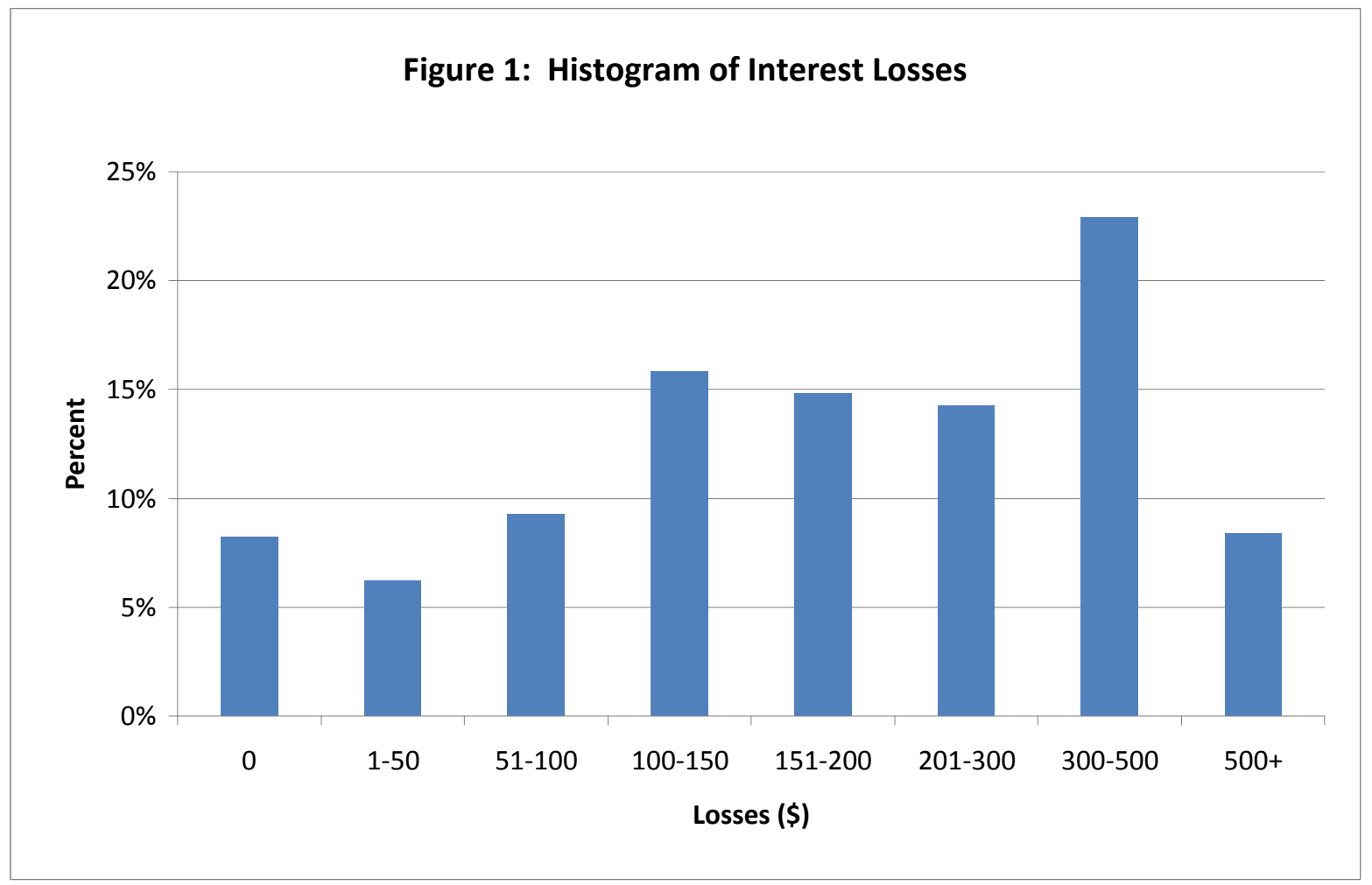


Table 1

Liquidity Declines as the Payday Borrowing Event Approaches

\begin{tabular}{ccccccc}
\hline \hline Lag Time Before & \multicolumn{3}{c}{ Liquidity Percentiles $(\$)$} & \multicolumn{2}{c}{ Liquidity $(\$)$} \\
the PDL (Months) & 90th & 75th & 25th & 10th & Mean & Std \\
\hline t-12 & 2557 & 2018 & 1069 & 478 & 1556 & 1036 \\
t-11 & 2581 & 2086 & 1070 & 440 & 1572 & 1171 \\
t-10 & 2531 & 2091 & 1118 & 395 & 1587 & 991 \\
t-9 & 2587 & 1841 & 1023 & 382 & 1413 & 1205 \\
t-8 & 2451 & 1739 & 867 & 357 & 1595 & 1104 \\
t-7 & 2460 & 1643 & 867 & 346 & 1421 & 1148 \\
t-6 & 2509 & 1585 & 804 & 334 & 1380 & 1118 \\
t-5 & 2319 & 1585 & 793 & 311 & 1396 & 899 \\
t-4 & 2348 & 1375 & 711 & 282 & 1284 & 842 \\
t-3 & 2280 & 1395 & 663 & 287 & 1249 & 818 \\
t-2 & 2171 & 1390 & 664 & 265 & 1122 & 722 \\
t-1 & 2177 & 1359 & 623 & 262 & 990 & 677 \\
t & 2102 & 1244 & 583 & 263 & 1011 & 653 \\
\hline \hline
\end{tabular}


Appendix Table A1

Summary Statistics: Credit Card Data

\begin{tabular}{|c|c|c|c|c|}
\hline & \multicolumn{2}{|c|}{ Unmatched Sample } & \multicolumn{2}{|c|}{ Matched Sample } \\
\hline & Mean & Std Dev & Mean & Std Dev \\
\hline \multicolumn{5}{|l|}{ Overall Characteristics } \\
\hline Fico Score & 729.57 & 69.20 & 673.44 & 67.61 \\
\hline Income & 62258.29 & 244547.48 & 34115.48 & 100286.85 \\
\hline Number of CC Accounts & 25.76 & 11.60 & 22.51 & 11.86 \\
\hline Open CC Accounts & 3.67 & 3.41 & 3.19 & 3.01 \\
\hline Open CC with balance & 2.14 & 2.37 & 2.63 & 2.50 \\
\hline Total Balance of CC & 6625.79 & 11640.12 & 10917.41 & 15355.09 \\
\hline \% Delinquent & $5.45 \%$ & $77.26 \%$ & $13.85 \%$ & $56.05 \%$ \\
\hline \multicolumn{5}{|l|}{ Issuer's Credit Card } \\
\hline Account Age (months) & 93.33 & 81.44 & 62.27 & 54.26 \\
\hline Behavior Score & 593.55 & 262.08 & 545.62 & 288.66 \\
\hline Credit Line & 7521.94 & 3665.30 & 3240.29 & 3652.78 \\
\hline Current Balance & 2968.02 & 2992.54 & 2479.44 & 2796.09 \\
\hline Chargeoff Amount & 4867.48 & 3817.89 & 3773.32 & 3588.47 \\
\hline Purchases & 256.42 & 744.62 & 240.49 & 75181.91 \\
\hline Number of Monthly Purchases & 2.01 & 3.30 & 1.85 & 3.54 \\
\hline APR & 17.57 & 5.71 & 18.23 & 6.37 \\
\hline Cycle Payments & 319.94 & 864.28 & 209.79 & 644.13 \\
\hline Monthly Payments & 340.08 & 908.27 & 343.59 & 96191.91 \\
\hline Debt & 1933.10 & 2840.80 & 2120.30 & 3218.55 \\
\hline Cycle Cash Withdrawl & 10.13 & 144.38 & 3.91 & 64.60 \\
\hline Cycle Purchases & 259.01 & 749.69 & 146.78 & 510.37 \\
\hline \multicolumn{5}{|l|}{ Other Accounts with this Issuer } \\
\hline Home Equity Balance & 2531.58 & 12620.68 & 1669.09 & 7586.31 \\
\hline Mortgage Balance & 43849.55 & 87776.67 & 31585.94 & 71495.08 \\
\hline Auto Balance & 3944.08 & 7335.66 & 2632.25 & 8369.89 \\
\hline \multicolumn{5}{|l|}{ Demographics } \\
\hline Female Applicant & $30 \%$ & $31 \%$ & $18 \%$ & $38 \%$ \\
\hline Co-Applicant & $11 \%$ & $32 \%$ & $22 \%$ & $41 \%$ \\
\hline Singles & $32 \%$ & $47 \%$ & $33 \%$ & $47 \%$ \\
\hline Age & 51.06 & 16.97 & 50.78 & 14.34 \\
\hline Number of Accounts & 143,228 & & 3090 & \\
\hline
\end{tabular}




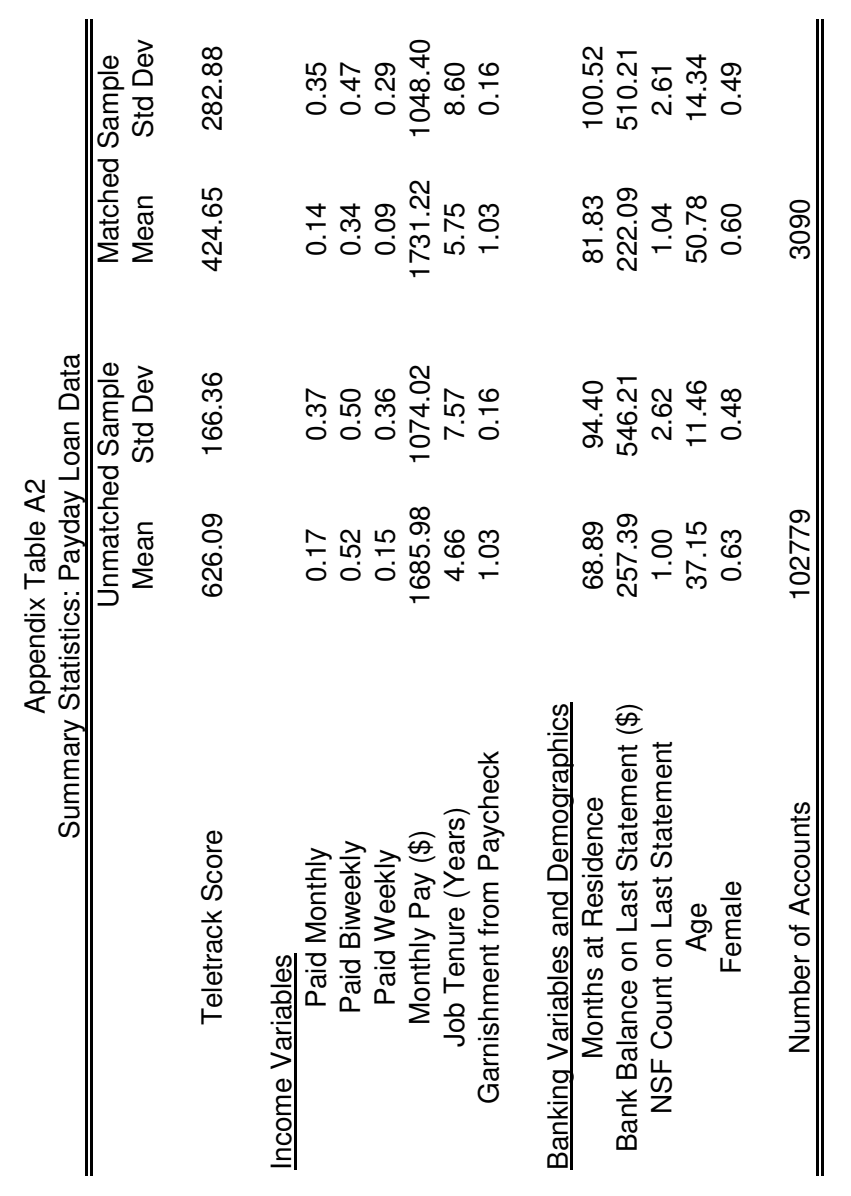


Appendix Table A3

Credit Card Liquidity and APRs in the Matched Sample

\begin{tabular}{|c|c|c|c|c|}
\hline A: FICO Ranges & Variables & Mean & Std & $\overline{\mathrm{N}}$ \\
\hline \multirow[t]{2}{*}{$<500$} & liquidity & -554.45 & 701.95 & 41 \\
\hline & apr & 24.48 & 3.22 & 41 \\
\hline \multirow[t]{2}{*}{$500-550$} & liquidity & -356.49 & 927.11 & 93 \\
\hline & apr & 23.66 & 5.43 & 93 \\
\hline \multirow[t]{2}{*}{$550-600$} & liquidity & 496.27 & 1698.95 & 216 \\
\hline & apr & 21.32 & 7.37 & 216 \\
\hline \multirow[t]{2}{*}{$600-650$} & liquidity & 711.81 & 2967.09 & 834 \\
\hline & apr & 20.39 & 6.95 & 834 \\
\hline \multirow[t]{2}{*}{$650-700$} & liquidity & 1099.00 & 3281.15 & 1153 \\
\hline & apr & 17.53 & 6.23 & 1153 \\
\hline \multirow[t]{2}{*}{$>700$} & liquidity & 2050.20 & 3797.71 & 753 \\
\hline & apr & 15.02 & 5.85 & 753 \\
\hline \multicolumn{5}{|c|}{ B: Revolvers/Transactors } \\
\hline \multirow[t]{2}{*}{ Debt Revolvers } & liquidity & 613.93 & 3082.05 & 2264 \\
\hline & apr & 19.05 & 6.71 & 2264 \\
\hline \multirow[t]{2}{*}{ Transactors } & liquidity & 2498.54 & 3604.64 & 826 \\
\hline & apr & 16.01 & 5.33 & 826 \\
\hline \multicolumn{5}{|l|}{ C: Single/Married } \\
\hline \multirow[t]{2}{*}{ Married } & liquidity & 1315.66 & 2277.76 & 2069 \\
\hline & apr & 18.24 & 6.32 & 2069 \\
\hline \multirow[t]{2}{*}{ Single } & liquidity & 720.11 & 3006.74 & 1021 \\
\hline & apr & 18.20 & 6.49 & 1021 \\
\hline \multicolumn{5}{|l|}{ D: Age Range } \\
\hline \multirow[t]{2}{*}{$<30$} & liquidity & 1091.01 & 4034.30 & 272 \\
\hline & apr & 18.79 & 6.30 & 272 \\
\hline \multirow[t]{2}{*}{$30-40$} & liquidity & 976.99 & 4189.46 & 535 \\
\hline & apr & 18.45 & 6.47 & 535 \\
\hline \multirow[t]{2}{*}{$40-50$} & liquidity & 896.28 & 4154.83 & 856 \\
\hline & apr & 17.95 & 6.61 & 856 \\
\hline \multirow[t]{2}{*}{$50-60$} & liquidity & 963.12 & 4466.89 & 802 \\
\hline & apr & 17.99 & 6.16 & 802 \\
\hline \multirow[t]{2}{*}{$60-70$} & liquidity & 1497.23 & 3908.58 & 334 \\
\hline & apr & 18.42 & 6.45 & 334 \\
\hline \multirow[t]{2}{*}{$>70$} & liquidity & 2048.72 & 3585.83 & 291 \\
\hline & apr & 18.53 & 5.85 & 291 \\
\hline
\end{tabular}

Notes: Calculated by the authors from matched administrative data. "Liquidity" refers to credit card liquidity on the days individuals take out their first payday loans. Liquidity is calculated as the difference between the credit limit on the credit card and the amount of outstanding debt. The APR is the average over accounts within the group and is not debt weighted. "Transactors" are defined as credit card account holders who paid their credit card bills in full in the one month before taking out their first payday loans. Note that each partition contains the total of 3090 people in the matched sample. 
Appendix Table A4

Correlates of Interest Losses

\begin{tabular}{cccc}
\hline \hline & & & \\
Variables & Coeff Value & Std Err & t-stat \\
\hline Constant & 133.71 & 26.91 & 4.97 \\
Ln(Income) (at T=1) & -1.55 & 0.35 & -4.41 \\
Gender (Female) & -7.03 & 6.90 & -1.02 \\
Marital Status & 17.41 & 5.69 & 3.06 \\
Age & -3.18 & 0.70 & -4.52 \\
Age Sq & 5.13 & 0.92 & 5.59 \\
FICO Scores (at T=1) & -0.99 & 0.07 & -13.39 \\
Fico Score Sq (at T=1) & -0.29 & 0.09 & -3.29 \\
\hline Number of Obs & 3090 & & \\
R Sq & 0.08 & & \\
\hline \hline
\end{tabular}

This Table reports the results of regressing LOSS on individual characteristics at the date of the credit card account holder's first payday loan. 


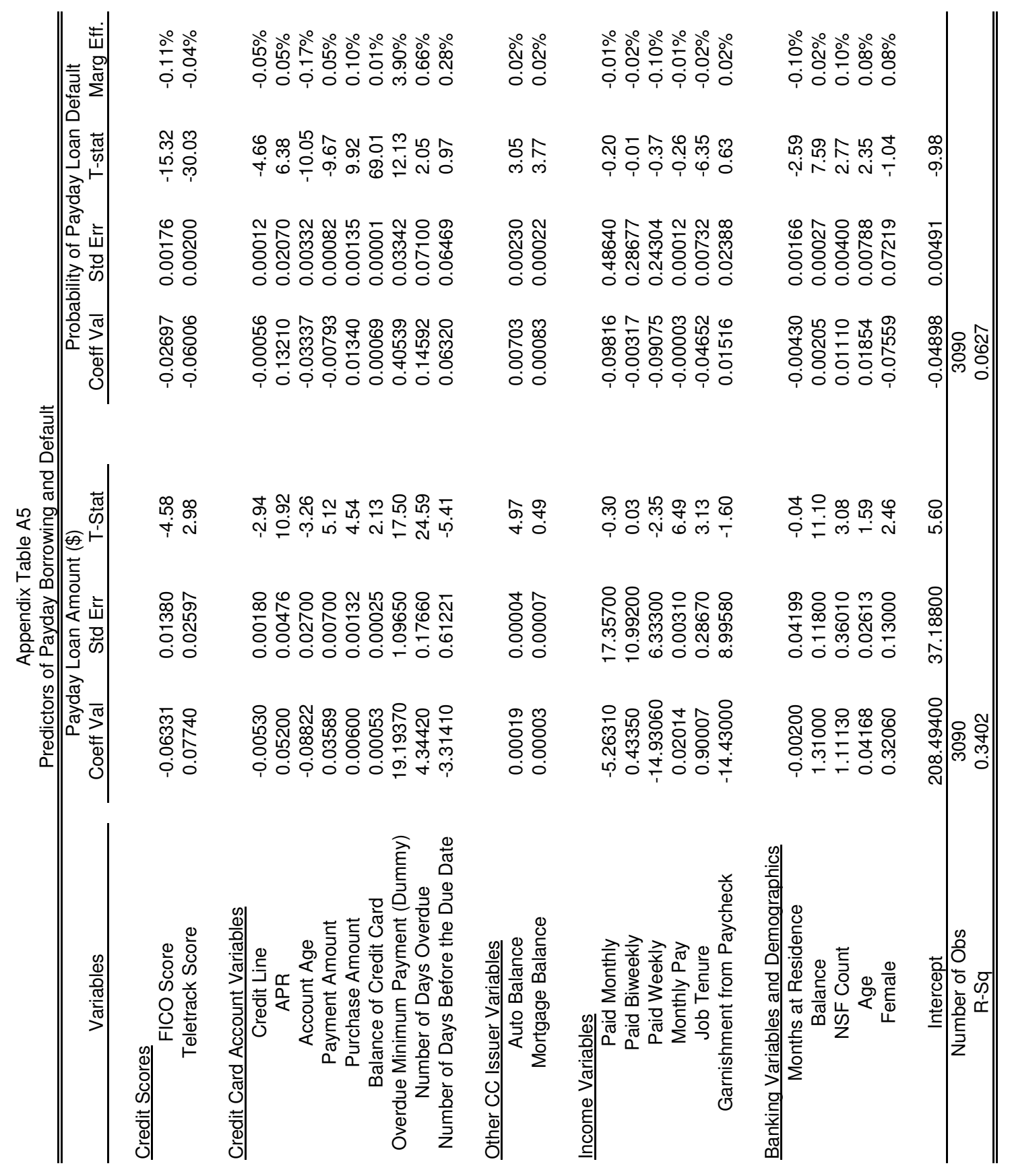




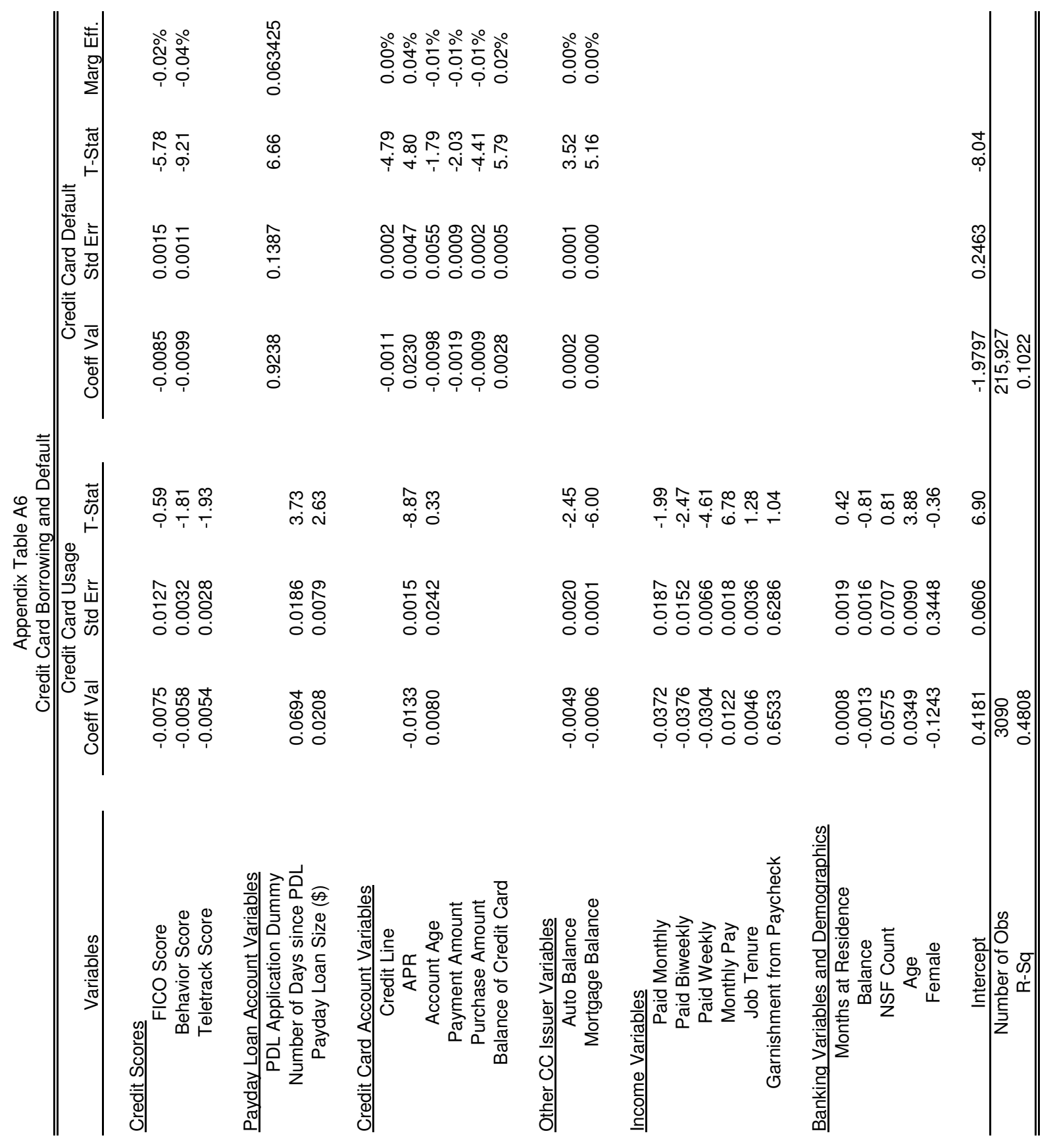

